\title{
Growth and Toxin Synthesis in Batch and Chemostat Cultures of Corynebacterium diphtheriae
}

\author{
R. C. RIGHELATO* AND P. A. VAN HEMERT \\ Rijks Instituut voor de Volksgezondheid, Bilthoven, The Netherlands
}

(Accepted for publication II July 1969)

SUMMARY

Toxin synthesis in restricted-iron batch cultures of Corynebacterium diphtheriae CN2000 (a PW8, PD strain) was proportional to the bacterial mass above a minimum bacterial concentration. During glucose-limited growth $0.30 \mathrm{~g}$. toxin was released/g. bacterial protein synthesized. In excess of glucose $0.06 \mathrm{~g}$. toxin was released $/ \mathrm{g}$. bacterial protein synthesized. Toxin release in glucose-limited continuous cultures followed similar kinetics to the batch cultures.

Iron in the restricted-iron medium, $6 \mu \mathrm{g}$. atom/l., limited the quantities of iron taken up by the bacteria and of three iron-containing enzymes, but did not restrict bacterial concentration over the range $2 \cdot 0-4.5 \mathrm{mg}$. bacterial protein $/ \mathrm{ml}$. The addition of $90 \mu \mathrm{g}$. atom $\mathrm{Fe} / \mathrm{l}$. to a restricted-iron culture rapidly inhibited toxin release.

\section{INTRODUCTION}

Diphtheria toxin is a synthesized by Corynebacterium diphtheriae when grown in medium whose iron content is very low (Pappenheimer \& Hendee, 1947). It is released from intact organisms (Pappenheimer, Miller \& Yoneda, 1962) and the very low intracellular concentrations of the toxin (Raynaud et al. 1954) indicate that it is released as soon as it is synthesized. The relationship between the formation of toxin and the growth of the bacterium is of interest for the light it may shed on the role of the toxin in the physiology of $C$. diphtheriae; a critical evaluation of this relationship is a prerequisite for the study of toxinogenesis.

Diphtherial toxin has been reported to be produced by the organisms under a variety of growth conditions. Hirai, Uchida, Shinmen \& Yoneda (I966) described a system in which toxin synthesis occurred for short periods of time ( 3 to $4 \mathrm{hr}$ ) without concomitant increase in cell mass. To obtain high titres of toxin, however, growing bacteria are used. Raynaud et al. (1954) showed an approximately constant relationship between increase in toxin concentration and increase in bacterial nitrogen over the greater part of the toxin production phase in batch cultures. Toxin release begins during the exponential phase of growth after a short lag and continues for variable lengths of time after exponential growth has ceased (Raynaud, I966; van Hemert \& van Wezel, 1966).

The shape of the growth curves on both the complex and the defined media used for diphtheria toxin production show that the cultures pass through at least two exponential stages, followed by a phase of decreasing growth rate (Raynaud, 1966). More-

* Present Address: Glaxo Laboratories Limited, Ulverston, Lancashire 
over, as growth progresses the bacteria are exposed to simultaneous changes in the concentrations of substrates utilized for growth, as well as of the products of growth. Steady-state chemostat cultivation (Monod, I950; Novick \& Szilard, 1950) eliminates the problem of sequential changes in the environment of the bacteria and allows the independent investigation of the effects of growth rate and cell concentration on toxinogenesis. The present paper shows that toxinogenic Corynebacterium diphtheriae can be maintained in steady-state continuous culture for indefinite lengths of time; this allowed the method to be used to study the inhibition of toxin synthesis by iron over long periods, whilst maintaining steady-state growth at the same rate.

\section{METHODS}

Organism. Corynebacterium diphtheriae $\mathrm{CN} 2000$, capable of yielding up to $0.30 \mu \mathrm{g}$. toxin protein/g. cell protein, was used. This strain originated from the PW8 strain (Park \& Williams, 1896). Professor W. L. Barksdale kindly examined this strain and has identified it as the $\mathrm{PW}_{S}$ (PD) strain (Barksdale, Garmise \& Rivera, I96I).

Medium. A papain digest of beef supplemented with salts and vitamins (Linggood \& Fenton, 1947), containing Kjeldahl-N 5 g./l. was used. The medium was ultrafiltered and analytical grade glucose added in the concentrations stated below. The medium contained 5 to $7 \mu \mathrm{g}$. atom $\mathrm{Fe} / \mathrm{l}$. unless otherwise stated.

Apparatus. Batch and continuous cultures were done in the glass-walled Bilthoven Unit of 10 1. total capacity (van Hemert, 1964). A vaned disc impellor operating at $650 \mathrm{rev} . / \mathrm{min}$. and producing a considerable vortex provided agitation and aeration. The partial pressure of dissolved oxygen $\left(\mathrm{pO}_{2}\right)$ was measured with a steam-sterilizable galvanic electrode (van Hemert, Kilburn, Righelato \& van Wezel, I969). The $\mathrm{pO}_{2}$ was controlled at $25 \mathrm{~mm}$. $\mathrm{Hg}$, by adding oxygen or nitrogen to a carrier stream of air in response to the signal of the electrode, while the total gas flow was held constant by a differential pressure regulator (Fischer and Porter) and adjusted to give an effluent carbon dioxide concentration of 5 to $7 \%(\mathrm{v} / \mathrm{v})$. The medium was controlled at $\mathrm{pH} 7 \cdot 3$ by adding $2 \mathrm{~N}-\mathrm{HCl}$ or $4 \mathrm{~N}-\mathrm{NaOH}$. An antifoam concentration of $\mathrm{r} \cdot 0 \mathrm{ml}$./1. medium was maintained by adding $3 \mu \mathrm{l}$. antifoam (polypropylene glycol P 2000, Dow Chemical Co.) at intervals of 0.5 to 2.0 min., depending on the dilution rate used. Temperature was controlled at $35^{\circ}$.

Assays. Diphtheria toxin concentration was measured by Ramon flocculation against the Dutch National Standard Antitoxin.

Extinctions of the bacterial suspensions were measured with a Vitatron photoelectric Colorimeter.

Cellular and extracellular protein was measured by the biuret method of Stickland (I95I) with crystalline bovine serum albumin as standard.

For all assays on cell material bacteria were washed twice in the cold with $0.05 \mathrm{M}$ phosphate buffer $\left(\mathrm{pH} \mathrm{7.3)}\right.$ and disrupted at 0 to $5^{\circ}$ for $30 \mathrm{~min}$. in an MSE $20 \mathrm{Kc} / \mathrm{s}$ ultrasonic disintegrator.

The enzyme assays and the methods for the measurement of iron in cells or medium are those described by Righelato (1969).

Glucose concentration was measured by a glucose oxidase method (blood sugar kit; Boehringer and Soehne GmbH, Mannheim, Germany). 


\section{RESULTS}

Toxin synthesis in batch cultures

On Linggood \& Fenton (1947) medium containing 25 g. maltose/1. after the initial exponential growth phase during which toxin synthesis began, the growth rate was probably limited by the rate at which the main carbohydrate source, usually maltose, was utilized (Tasman \& Brandwijk, 1940). In the present work glucose replaced maltose, but to obtain a prolonged phase of toxin production it was supplied at a

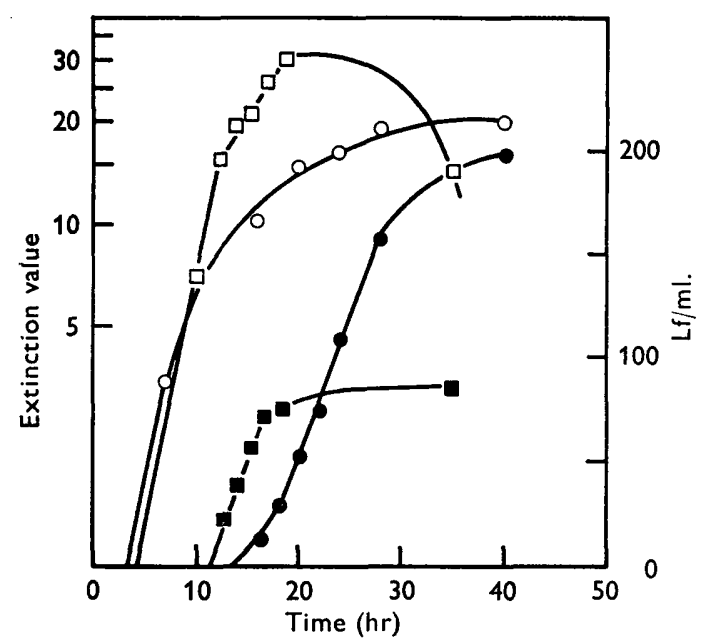

Fig. I

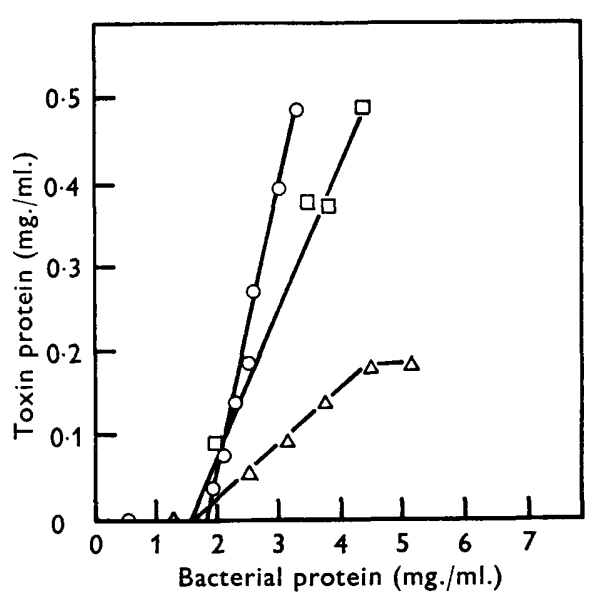

Fig. 2

Fig. I. Growth and toxin production by Corynebacterium diphtheriae $\mathrm{CN} 200$ on Linggood \& Fenton (1947) medium with glucose in excess and with glucose-limited growth. $\square$, Glucose excess ( 5 g./l. throughout culture period); $O$, glucose-limited growth. Glucose was added to the culture slowly to maintain at pH 7.0 (van Hemert \& van Wezel, 1966). Open symbols, extinction of culture; closed symbols, toxin concentration, $\mathrm{Lf} / \mathrm{ml}$.

Fig. 2. The amount of toxin produced by $C$. diphtheriae $\mathrm{CN} 2000$ at increasing bacterial concentrations in batch cultures and steady state chemostat cultures. $O$, Batch culture to which glucose was fed at a growth-limiting rate (data from Fig. I); $\Delta$, batch culture in which the glucose concentration was 5 g./l. throughout (data from Fig. I); $\square$, glucose-limited chemostat culture. Each point represents a steady state obtained at a different concentration of glucose in the medium, and at a dilution rate of $0.05 \mathrm{I} \mathrm{hr}^{-1}\left(\right.$ At $D=0.05 \mathrm{I} \mathrm{hr}^{-1} 9 \mathrm{~g}$. glucose gave I g. bacterial protein; the medium without added glucose gave $\mathrm{I} \cdot 5 \mathrm{~g}$. bacterial protein/l.)

slow growth-limiting rate (van Hemert \& van Wezel, 1966). When, instead, the glucose concentration was maintained at a high value $(>5 \mathrm{~g} . / 1$.) throughout the incubation period, growth at the maximum rate continued for longer but slowed suddenly and toxin synthesis terminated early (Fig. I). The maximum specific growth rate of Corynebacterium diphtheriae $\mathrm{CN} 2000$ on the Linggood \& Fenton medium used was $0.35 \mathrm{hr}^{-1}$ (doubling time, $120 \mathrm{~min}$.). At high glucose concentrations, though respiration was not diminished, the organism fermented the sugar rapidly, resulting in the extracellular accumulation of acids; hence addition of considerable quantities of alkali was required to maintain the culture at $\mathrm{pH} 7 \cdot 3$.

The addition of iron ( $90 \mu \mathrm{g}$. atom/1.) to a culture completely inhibited toxinogenesis 
but did not influence the final bacterial concentration; thus iron was not growthlimiting. It is possible, however, that the decrease of the intracellular iron concentration below a critical value is necessary for toxin synthesis, as suggested by Pappenheimer (1955). If this is so, then toxin will not be synthesized until the cell concentration is high enough to decrease the iron concentration to the critical value. In Fig. 2 the cell concentration is related to the toxin concentration. In both glucose-limited and excess glucose cultures no significant quantities of toxin (detectable by flocculation with anti-toxin) were produced before the cell concentration rose above $\mathrm{I} \cdot 6 \mathrm{~g}$. bacterial protein/l., at which time the iron content of the bacteria was 2.5 to 3.0 $\mu \mathrm{g}$. atom $\mathrm{Fe} / \mathrm{g}$. bacterial protein.

The culture grown with excess glucose, where the growth rate was high during most of the toxin production phase, gave a lower yield of toxin per increment of cell concentration ( $0.06 \mathrm{~g}$. toxin protein $/ \mathrm{g}$. bacterial protein) than in the slower growing glucose-limited cultures $(0.30 \mathrm{~g}$. toxin protein/g. bacterial protein).

\section{Toxin synthesis in chemostat cultures}

In chemostat cultures the growth rate is determined by the rate at which medium is fed to the culture, one component of the medium being used to limit the total amount of cell material produced. In the steady state the specific growth rate is equal to the dilution rate (the flow rate of medium into the culture divided by the volume of the culture). Since glucose could be used to limit the growth rate in batch cultures of Corynebacterium diphtheriae whilst allowing a high rate of toxin synthesis, it was used as the growth limiting substrate in chemostat cultures. A preliminary description of the continuous culture system has been given elsewhere (Righelato \& van Hemert, I969).

The chemostat cultures were done at growth rates between 0.100 and $0.027 \mathrm{hr}^{-1}$. The highest yields of toxin and the highest proportion of toxin protein to cell protein was obtained at the growth rate $0.05 \mathrm{I} \mathrm{hr}^{-1}$. This growth rate was used for the experiments described below. The steady-state at the dilution rate $0.05 \mathrm{I} \mathrm{hr}^{-1}$ with 15.5 g. glucose/l. limiting growth has been repeated on several occasions giving a bacterial concentration of $3 \cdot 15 \mathrm{~g}$. protein/l., an extracellular protein concentration of $\mathrm{I} \cdot \mathrm{II} \mathrm{g} . / 1$ of which $0.3 \mathrm{I} \mathrm{g} / 1$. was toxin $(=155 \pm 15 \mathrm{Lf} / \mathrm{ml}$.). Bacterial concentration, extracellular protein and toxin titre remained stable over several weeks of continuous cultivation.

Figure 2 shows the relationship between toxin titre and the cell concentration in batch and chemostat cultures. The results indicate that, in chemostat cultures as in batch cultures, below a minimum cell concentration toxin was not produced. The minimum cell concentration corresponded to an intracellular concentration of iron of $2 \cdot 7 \mu \mathrm{g}$. atom/g. bacterial protein (Fig. 3). The concentration of intracellular non-heme iron and of three iron-containing enzymes (expressed per unit of culture volume instead of per unit of cell mass) did not vary with cell concentration (Table r). Thus it would appear that the concentration of these enzymes was in fact limited by the low iron concentration.

As in batch cultures, the addition to the culture medium of $90 \mu \mathrm{g}$. atom $\mathrm{Fe} / 1$. completely inhibited toxin synthesis (Table 2). Immunodiffusion tests of supernatant fluids of the steady-state excess-iron culture and the steady-state restricted-iron 
culture were made with a monospecific antidiphtherial serum (kindly supplied by Professor M. Raynaud) and a crude antidiphtherial serum which gave 7 to 8 precipitation lines with the culture supernatant fluid, the heaviest being the toxin. The toxin precipitation line could only be found in the restricted-iron culture samples; the other lines were present in both restricted-iron and excess-iron samples. The antigens of the culture supernatant fluids, other than the toxin, were also found, in higher concentrations, in bacterial extracts; their presence in the culture supernatant fluids may have been due to lysis of some of the bacteria. The higher concentration of non-toxic

Table $\mathrm{I}$. The relationship between bacterial concentration and iron and some ironcontaining enzymes of Corynebacterium diphtheriae CN 2000 in glucose-limited chemostat culture

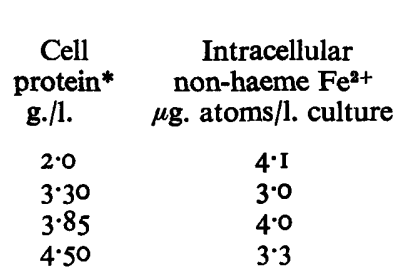

Bacterial
Cytochrome b
extinction
(units/l. culture)
8
9
I0
8

$\begin{array}{cc}\begin{array}{c}\text { Succinate } \\ \text { dehydrogenase } \\ \mathrm{m} \mu \text { mole/ml./min. }\end{array} & \begin{array}{c}\text { Catalase } \\ \text { Kobs. sec. }{ }^{-1}\end{array} \\ - & - \\ 140 & 10 \cdot 4 \\ 190 & 12 \cdot 2 \\ \text { I40 } & 12 \cdot 2\end{array}$

* Cell protein concentration was varied by varying the concentration of glucose in the medium, 9 g. glucose gave I g. bacterial protein. The medium without added glucose gave I.5 g. bacterial protein/l.

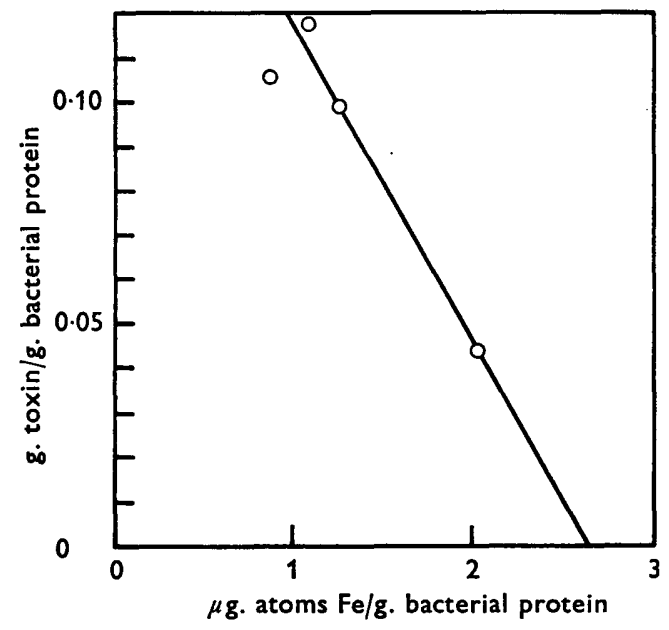

Fig. 3

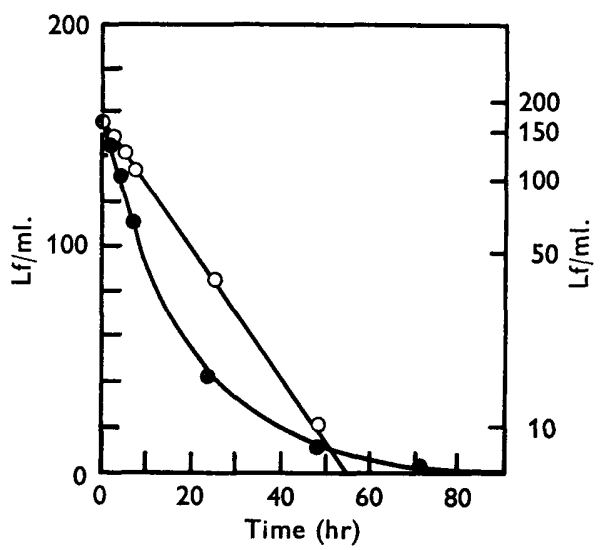

Fig. 4

Fig. 3. The relationship between intracellular iron concentration and toxin synthesis by Corynebacterium diphtheriae $\mathrm{CN} 2000$ in glucose-limited chemostat cultures. The medium contained $6 \mu \mathrm{g}$. atom $\mathrm{Fe} / \mathrm{l}$. The concentration of iron in the bacteria was varied by varying the bacterial concentration by changing the concentration of glucose in the medium; $9 \mathrm{~g}$. glucose gave $\mathrm{I} \mathrm{g}$. bacterial protein. The medium without added glucose gave $\mathrm{I} \cdot 5 \mathrm{~g}$. bacterial protein/l.

Fig. 4. The dilution out of toxin from glucose-limited chemostat cultures of $C$. diphtheriae CN2000 after inhibition of toxinogenesis by iron. At $\mathrm{O}$ hr the iron concentration in the vessel and in the medium was increased from $7 \mu \mathrm{M}$ to $97 \mu \mathrm{M}$. Dilution rate $0.05 \mathrm{I} \mathrm{hr-1}$. 0 , Linear scale; 0 , logarithmic scale. 
extracellular protein in the restricted-iron cultures, described here and also observed by Alouf (1958) may reflect an increased liability of the iron-deficient bacteria to lysis.

Table 2 shows that iron addition, besides inhibiting toxin synthesis, brought about an increase in the concentration of diphtherial cytochrome $b_{559}$ the major haemecontaining enzyme of the PW 8 (PD) strain of Corynebacterium diphtheriae (Pappenheimer \& Hendee, 1947).

Table 2. The effect of iron on the steady-state cell concentration and extracellular protein formation by Corynebacterium diphtheriae CN 2000 in glucose-limited chemostat culture*

Fe in medium $\mu \mathrm{g}$. atom/1.:

Cell protein $\mathbf{g} / 1$. :

Non-toxin extracellular protein* g./l.:

Toxin protein $\dagger$ g./l.:

Cell non-haeme Fe $\mu \mathrm{g}$. atom/1.:

Cyt. $b$ absorbtion units/l.:

$\begin{array}{cc}7 & 97 \\ 3.85 & 4.33 \\ 0.94 & 0.38 \\ 0.32 & 0 \\ 4.0 & 60 \\ 10.8 & 40\end{array}$

* Total trichloroacetic acid precipitable protein in culture supernatant fluid less toxin protein.

$\uparrow$ Calculated, assuming I Lf $=2.44 \mu \mathrm{g}$. protein.

The kinetics of disappearance of toxin from the culture indicate the rapidity with which toxin release was inhibited. In continuous culture the formation of a cell product at a constant rate results, in the steady state, in a constant concentration of the product $\left(C_{0}\right)$ in the vessel. A step change may be applied to the culture, for instance the addition of an inhibitor, and the product present in the vessel before the application of the change is washed out exponentially by the continuous addition of fresh medium:

$$
\begin{gathered}
C_{t}=C_{0} e^{-D t} \\
\text { and } \ln C_{t}=\ln C_{0}-D t,
\end{gathered}
$$

where $C_{t}$ is the product concentration $t$ hours after imposition of the step change and $D$ the dilution rate. If washout is to follow these kinetics the time for the inhibitor to exert maximum inhibition will be small compared to the mean residence time (1/D) of the culture.

The disappearance of toxin from the culture following the addition of iron is shown in Fig. 4 on a linear scale and plotted according to equation (2). The natural logarithm of the toxin concentration $\left(C_{t}\right)$ falls linearly with a slope equal to $-\mathrm{D}$ and intercepts the ordinate at the zero time toxin concentration $\left(\ln C_{0}\right)$. The inhibition of toxin synthesis thus was complete and immediate, to within the accuracy of measurement, upon the addition of the inhibitor.

\section{DISCUSSION}

Toxin synthesis by Corynebacterium diphtheriae CN 2000 in glucose-limited batch cultures and in steady-state glucose-limited chemostat cultures followed similar kinetics insofar as toxin release was proportional to the bacterial concentration above a minimum value. The limitation of growth by glucose, or the slowly hydrolysed sugar maltose, was necessary to obtain a high ratio of toxin protein to bacterial protein. During the toxinogenic phase of iron-deficient glucose-limited batch cultures 
the rate of toxin production was $0.30 \mathrm{~g}$. toxin protein/g. bacterial protein synthesized, whereas in excess of glucose toxin release occurred at $0.06 \mathrm{~g}$. $\mathrm{g}$. bacterial protein synthesized. Under glucose-limited growth conditions, therefore, a single protein, the toxin, represented a large proportion of the protein synthesized by the bacteria.

Whereas toxin synthesis in batch cultures ceased after about $30 \mathrm{hr}$ of slow growth, the glucose-limited continuous cultures could be maintained for weeks without decrease in the rate of toxin synthesis or change in bacterial concentration. Similar stable continuous cultures of toxin-producing Clostridium tetani have been reported by Zaccharias \& Bjorklund (1968). Pirt, Thackeray \& Harris-Smith (I96I), however, who were concerned with a cell-bound antigen of Pasteurella pestis, reported a progressive decrease in titre during continuous culture.

Significant quantities of diphtheria toxin were not released in batch cultures until the intracellular iron concentration had fallen below about $3.0 \mu \mathrm{g}$. atom/g. cell protein. A similar minimum intracellular concentration of iron below which toxin synthesis did not occur in chemostat cultures was found to be $2 \cdot 7 \mu \mathrm{g}$. atom $\mathrm{Fe} / \mathrm{g}$. cell protein. Edwards \& Seamer (1960), who worked with the same strain and a similar medium, found, by varying the iron concentration in their batch culture medium, that the intracellular iron concentration had to fall below $3 \mu \mathrm{g}$. atom $\mathrm{Fe} / \mathrm{g}$. bacterial dry weight for toxin synthesis to occur. In our glucose-limited cultures the cell protein:dry weight ratio was $0.48: 1 \cdot 0$; thus Edwards \& Seamer's critical intracellular iron concentration was approximately $50 \%$ of that found in the present work.

In steady-state chemostat culture at a low iron concentration $(6 \mu \mathrm{g}$. atom/l.) the concentrations of several iron-containing enzymes did not increase with bacterial concentration. It appears, then, that the concentrations of iron-containing cell components were limited by the low iron concentration of the medium and that the bacteria can be regarded as iron deficient. Under these conditions the amount of toxin synthesized by the bacteria was lower at the lower bacterial concentrations, the amount of iron per unit of bacterial mass being higher.

A high concentration of iron added to a steady-state toxin-producing chemostat culture was completely and immediately inhibitory to toxin synthesis, as suggested by Barksdale et al. (196I). These authors found that iron added to u.v.-induced toxinogenic Corynebacterium diphtheriae at various times after induction decreased the yield of toxin to that given by the iron-free control at the time of addition.

The mechanism of the inhibition of toxinogenesis by iron remains to be established. The addition of iron to iron-exhausted toxinogenic bacteria caused, in addition to inhibition of toxinogenesis, an increase in the concentration of cytochrome $b$, the main haeme-containing enzyme. If the mM extinction coefficient of diphtherial cytochrome $b$ is of the same magnitude as that of cytochrome $b$ from other sources (about 30) the cytochrome concentration is about $0.3 \mu \mathrm{M}$ in the toxin-producing cultures described here and $\mathrm{I} \cdot 4 \mu \mathrm{M}$ in the iron-inhibited culture. Since the intracellular iron concentrations in the low and high iron cultures were 4 and $60 \mu \mathrm{g}$. atom/l., respectively, cytochrome $b$ accounts for only a small proportion of the iron in the cells, most being present as non-haeme iron. The distribution of iron in Corynebacterium diphtheriae and the changes in haeme and non-haeme iron-containing enzymes concomitant with the inhibition of toxinogenesis have been studied and will be reported elsewhere (Righelato, 1969). 
We wish to thank Mr P. Smid and Mr G. van Praag for expert technical assistance. One of us (R.C.R.) was a NATO Research Fellow at the Rijks Instituut voor de Volksgezondheid.

\section{REFERENCES}

Alouf, J. E. (1958). Etude physiologique et biochimique de la toxinogénèse diphtérique. Ph.D. thesis, University of Paris, Faculty of Pharmacy, Series E. No. 60.

Barksdale, W. L., Garmise, L. \& Rivera, R. (1961). Toxinogeny in Corynebacterium diphtheriae. J. Bact. 81, 527.

EDWARDS, D. C. \& SeAmer, P. A. (1960). The uptake of iron by Corynebacterium diphtheriae growing in submerged culture. J. gen. Microbiol. 22, 705.

vaN Hemert, P. A. (1964). The Bilthoven Unit for submerged cultivation of micro-organisms. Biotech. Bioeng. 6, 381.

van Hemert, P. A. \& van Wezel. A. L. (1966). The course of pH in diphtheria toxin producti on Symp. Series immunobiol. Standard. 3, 221. Basel \& New York: Karger.

van Hemert, P. A., Kilburn, D. G., Righelato, R. C. \& VAN Wezel, A. L. (I969). A steam sterilisable electrode of the galvanic type for the measurement of dissolved oxygen. Biotech. Bioeng. (in Press),

Hirai, T., Uchida, T., Shinmen, Y. \& Yoneda, M. (1966). Toxin production by Corynebacterium diphtheriae under growth-limiting conditions. Biken J. 9. 19.

LingGoOD, F. V. \& FenToN, E. L. (1947). The production of diphtheria toxin by submerged culture in shaking flasks. Br. J. exp. Path. 28, 354 .

Monod, J. (1950). La technique de culture continue. Théorie et applications. Annls Inst. Pasteur, Paris 79, 390.

Novick, A. \& Szilard, L. (1950). Description of the chemostat. Science, N.Y. 112, 715.

Pappenheimer, A. M., Jun. (1955). The pathogenicity of diphtheria. Symp. Soc. gen. Microbiol. 5, 40.

Pappenheimer, A. M., Jun. \& Hendee, E. D. (1947). Diphtheria toxin. IV. The iron enzymes of Corynebacterium diphtheriae and their possible relation to diphtheria toxin. J. biol. Chem. I67, 701 .

Pappenheimer, A. M., Jun., Miller, P. A. \& Yoneda, M. (1962). Kinetics of diphtheria toxin formation. J. gen. Microbiol. 28, 531 .

Park, W. H. \& Williams, A. W. (1896). The production of diphtheria toxin. J. exp. Med. I, 164 .

Pirt, S. J., Thackeray, E. J. \& Harris-Smith, J. (196I). The influence of environment on antigen production by Pasteurella pestis studied by means of the continuous flow technique. J. gen. Microbiol. 25, 119.

Raynaud, M. (1966). Relation between growth and toxin synthesis. Symp. Series immunobiol. Standard. 3, 183. Basel \& New York: Karger.

Raynaud, M., Turpin, A., Mangalo, R., Bizzini, B. \& Pery, R. (I954). Growth and toxinogenesis. Annls Inst. Pasteur, Paris 87, 599.

Righelato, R. C. (1969). The distribution of iron in iron-deficient toxin-synthesising and in excessiron non-toxin-synthesising Corynebacterium diphtheriae. J. gen. Microbiol. 58, 411.

Righelato, R. C. \& VAN HeMERT, P. (1969). Toxinogenesis in continuous cultures of Corynebacterium diphtheriae. Proceedings of $4^{\text {th }}$ International Symposium on Continuous Culture of Micro organisms. Prague: Academia.

STICKLAND, L. H. (195I). The determination of small quantities of bacteria by means of the biuret reaction. J. gen. Microbiol. $5,698$.

TASMAN, A. \& BRANDWIJK, A. C. (1940). Experiments on metabolism with Corynebacterium diphtheriae III. J. infect. Dis. 67, 282.

ZaCChaRIAs, B. \& BJörKLUND, M. (1968). Continuous production of Clostridium tetani toxin. Appl. Microbiol. r6. 69. 